\title{
Sperm Quality in Holstein Bulls Friesian and Brahmans of Frozen Semen Commercially
}

\author{
Alejandro Córdova-Izquierdo ${ }^{1 *}$, Gustavo Ruiz-Lang1, Román Espinosa-Cervantes ${ }^{1}$, \\ Adrían Emmanuel Iglesias-Reyes', Maximino Méndez-Mendoza², Rubén Huerta-Crispín², \\ Abel Edmundo Villa-Mancera², Ma. De Lourdes Juárez-Mosqueda ${ }^{3}$, \\ Pedro Sánchez-Aparicio ${ }^{4}$, Jaime Olivares-Pérez ${ }^{5}$, Juan Eulogio Guerra-Liera6, \\ Gerardo Cansino-Arroyo ${ }^{7}$ \\ ${ }^{1}$ Departamento de Producción Agrícola y Animal, Universidad Autónoma Metropolitana Unidad Xochimilco, \\ México D.F., México \\ ${ }^{2}$ Facultad de Veterinaria, Benemérita Universidad Autónoma de Puebla, Puebla, México \\ ${ }^{3}$ Departamento de Morfología, FMVZ-UNAM, México D.F., México \\ ${ }^{4}$ Facultad de Veterinaria, Universidad Autónoma del Estado de México, Toluca, México \\ ${ }^{5}$ Unidad Académica de Medicina Veterinaria y Zootecnia, Universidad Autónoma de Guerrero, Guerrero, \\ México \\ ${ }^{6}$ Facultad de Agronomía, Universidad Autónoma de Sinaloa, Culiacán, México \\ ${ }^{7}$ División Académica de Ciencias Agropecuarias, Universidad Juárez Autónoma de Tabasco, Villahermosa, México \\ Email: ${ }^{*}$ acordova@correo.xoc.uam.mx
}

Received 27 March 2015; accepted 11 May 2015; published 15 May 2015

Copyright (C) 2015 by authors and Scientific Research Publishing Inc.

This work is licensed under the Creative Commons Attribution International License (CC BY).

http://creativecommons.org/licenses/by/4.0/

(c) (i) Open Access

\section{Abstract}

The aim of this study was to assess sperm quality (motility, viability and acrosomal integrity) sperm from commercially frozen semen straws two breeds of bulls Bos taurus (holstein Frisian) and Bos indicus (Brahman). 9 commercial straws $0.5 \mathrm{ml}$ of Holstein bull semen and 9 Brahman bull were thawed, they were kept for two hours at room temperature and motility, viability and acrosomal integrity (NAR) was assessed. The results were $30 \%$ motility, viability $40 \%$ and $30 \%$ of NAR in the Holstein breed. Brahma race for motility $40 \%, 50 \%$ and $40 \%$ viability was obtained NAR. In conclusion, according to the results of the variables analyzed, the Brahman breed in sperm quality was better than the Holstein breed; however, the results of both races meet minimum standards of quality sperm for use in artificial insemination (AI) field level.

\section{Keywords}

Semen Thawed, Bulls, Frozen Semen, Sperm Quality

*Corresponding author. 


\section{Introduction}

The freeze-thaw process, affecting approximately $50 \%$ of the sperm survival, is mainly due to the effect of these processes on the membrane, motility and sperm nuclei. It is considered that the primary site of damage associated with temperature changes are the sperm membranes [1]. The reduced fertility associated with frozenthawed semen was largely attributed to alteration of the structure and function of sperm membranes during the cooling process, freezing and thawing. For the sperm can fertilize the egg, must maintain their motility, viability and acrosomal membrane integrity [2].

The main parameters to be measured in semen after thawing are motility, viability and acrosomal integrity [3]-[6].

The aim of this study was to assess sperm quality (motility, viability and acrosomal integrity) sperm from commercially frozen semen straws two breeds of bulls Bos taurus (holstein frisian) and Bos indicus (Brahman).

\section{Material and Methods}

$180.5 \mathrm{ml}$ straws of bull semen, including 9 with semen from Holstein and 9 Brahman thawed. The straws with semen of both races were thawed in a water bath at $35^{\circ} \mathrm{C}$ for 35 seconds, they are perfectly dried, uncovered and semen was deposited in tubes Ependorf to assess immediately after motility, viability and NAR [7], semen thawed stored at room temperature for two hours and assessments were made every hour.

\section{Results}

The results obtained are shown in the following Table 1.

Table 1. Average percentages obtained valued variables.

\begin{tabular}{cccc}
\hline Race & & Masures variables & \\
& Motility & Viability & NAR \\
\hline Holstein & 30 & 40 & 30 \\
Brahman & 40 & 50 & 40 \\
\hline
\end{tabular}

NAR: acrosomal integrity.

\section{Discussion}

Sperm quality is measured through motility, viability and NAR, whose importance is reflected in the fertility of semen used in animal production unit.

In Holstein, an average of 30, 40 and 30 was obtained; Brahma in $40 \%, 50 \%$ and $40 \%$ motility, viability and NAR, respectively; These percentages were higher than those obtained by [8], who noted that these percentages decreased of $10 \%$ - 15\% within 2 hours of incubation and minimum standards for progressive motility were $25 \%$ at 0 hours and with temperature resistance of $15 \%$ at 2 hours [2] [3] [5].

In conclusion, according to the results of the variables analyzed, the Brahman breed in sperm quality was better than the Holstein breed; however, the results of both races meet minimum standards of quality sperm for use in artificial insemination (AI) field level.

\section{References}

[1] De Jarnette, J.M. (2005) The Effect of Semenquality on Reproductive Efficiency. Veterinary Clinics of North America: Food Animal Practice, 21, 409-418. http://dx.doi.org/10.1016/j.cvfa.2005.02.011

[2] Stornelli, M.C., Tittarelli, C.M., Savignone, C.A. and Stornelli, M.A. (2005) Efecto de los procesos de criopreservación sobre la fertilidad seminal. Analecta Veterinaria, 25, 28-35.

[3] Muíño, R., Fernández, M., Areán, H., Viana, J.L., Fernández, A. and Peña, A.I. (2002) Influencia de la raza y la edad en parámetros cinéticos de eyaculados bovinos. Centro de Selección y Reproducción Animal de Galicia, Xenética Fontao, 27, 10-11.

[4] Gasque, G. (2003) Enciclopedia del ganado bovino. Facultad de Medicina Veterinaria y Zootecnia, Universidad Nacional Autónoma de México, 183-189. 
[5] Hidalgo, O.C.O., Tamargo, M.C. and Díez, M.C. (2003) Análisis Del Semen Bovino. Boletín Informativo del SERIDA, 2, 39-43.

[6] Ordóñez, H.O.C., Tamargo, M.C. and Monforte, D.C. (2005) Análisis del semen bovino. Tecnología Agroalimentaria, 2, 39-43.

[7] Gómez, M. (2003) Evaluación del Semen. Revista Protocolo Evaluación de Semen en Rumiantes, 10, 1-9.

[8] Catena, C. (2002) Evaluación del semen de Bovino congelado. Revista Producción Bovina de Carne, 1, 18-20. 